\title{
Determining the nutrient content, energy, and in vitro true digestibility of some grass forage plants
}

\author{
Esra Gürsoy ${ }^{1 *}$, Adem Kaya², Mehmet Gül³ \\ ${ }^{1}$ Ağrı İbrahim Çeçen University, Celal Oruç Vocational School of Animal Husbandry, Ağrı, Turkey, ${ }^{2}$ Atatürk University, Faculty of Agriculture, \\ Department of Animal Science, Erzurum, Turkey, ${ }^{3}$ Atatürk University, Faculty of Veterinary Medicine, Department of Zootechnics and Animal \\ Nutrition, Erzurum, Turkey
}

\section{A B S TR A C T}

\begin{abstract}
The purpose of this study was to compare the chemical composition, metabolizable energy, net energy lactation, total digestible nutrient, in vitro digestion parameters, and relative feed quality of some grass forage plants growing naturally in the meadows and pastures of Erzurum province in Turkey. Orchardgrass (Dactylis glomerata), Variegated brome (Bromus variegatus), and Intermediate wheatgrass (Agropyron intermedium) were used as the research material. In this study, the metabolizable energy (ME) and net energy lactation (NEL) contents of the green grass crops forage plants were determined by in vitro gas production method, and their digestibility parameters and relative feed quality (RFQ) by the neutral detergent fiber (NDF) procedure using an Ankom Daisy incubator. As a result of the study, the differences between the forage plants were found to be statistically significant in terms of chemical composition, metabolizable energy, net energy lactation, true organic matter digestibility (TOMD) and RFO $(P<0.05)$. While the green intermediate wheatgrass was found to have the highest crude protein (CP) $(19.56 \%)$, crude fat (CF) $(3.06 \%)$, dry matter (DM) $(9.14 \%)$, ME $(8.82 \%)$, NEL (5.42\%), and TOMD $(97.75 \%)$; the green variegated brome was found to have the highest RFO (149.79). The green orchardgrass was found to have the highest contents of neutral detergent fiber (NDF), acid detergent fiber (ADF), and acid detergent lignin (ADL) with 66.23\%, 34.14, and 8.52\%, respectively. In conclusion, the green grass forage plants examined in this study can be used to eliminate the quality roughage deficit.
\end{abstract}

Keywords: Green grass crops; In vitro true digestibility; Metabolizable energy; Net energy; Relative feed quality

\section{INTRODUCTION}

Meadows and pastures have an important place in animal feeding thanks to the abundance of quality roughages and the cheapest feed source they offer in grazing seasons. The need for quality animal products increases with the increasing population; however, the need for quality roughage cannot be met due to the unconscious use of meadows and pastures (Alçiçek, 2001). Therefore, it has become a necessity to protect our meadows and pastures by improvement works and conscious use and to introduce novel forage crops in field agriculture. Meadow and pasture grasses are categorized into three groups: cereals, legumes, and other miscellaneous plants. Grass forage plants account for the largest share in meadows and pastures (Yancheva et al. 2002). This is thanks to their competitive abilities and longer shelf lives. Cereals are easily digestible by ruminants and offer a rich nutrient biomass. Moreover, they protect the soil from water and wind erosion thanks to their ability of developing dense grass (Sevov et al. 2018). They are more resistant to grazing and have a better adaptation ability compared to legumes (Serin and Tan, 2009). Grass forage plants that produce feeds rich in carbohydrates are mixed planted with legumes as a solution to the bloating problem caused by some legumes (Barsila, 2018). What makes the best use of the nitrogen that is brought to the soil symbiotically by legumes is the grass forage plants (Sayar and Kendal, 2014).

In forage plants, quality is associated with the contents of nutrients and toxic substances. It is affected many factors such as ecological conditions, plant species and variety, harvest time, and fertilizer (Gülcan et al. 2002; Ayasan et al., 2021). Feed quality, that is, the capacity to provide the desired nutrients to ruminant animals, (Adesogan et al., 2006; Newman et al., 2006; Muir et al., 2007) is economically important in selling or purchasing (Schut et al., 2010). Total nutrient digestibility (TND) and crude protein $(\mathrm{CP})$ content are used as an indicator for the quality of the feed (France, 2000; Pinkerton, 2005; Oyedele et al., 2016). It was reported that RFQ (relative feed quality) 
of forage plants could be used as a criterion to meet the nutritional needs of dairy cattle, and the RFQ needs of dairy cattle were classified by physiological periods as in Table 1 (Undersander, 2003).

In their study on this subject, Salama et al. (2016) compared the feed quality of grasses and legumes and reported that the method of RFQ grading of forage crops was quite effective in production for high yielding dairy cows and young animals. Favrea et al. (2019) investigated the forage quality of an intermediate wheat plant and red clover in monoculture in the spring, summer, and autumn in the first production year and reported the RFQ of the monoculture as 175 in the spring, 65 in the summer, and 116 in the autumn. They also reported that the nutritional value of the wheatgrass harvested in the autumn was suitable for cattle, dairy cows, and growing heifers.

It is very important to determine not only the nutrient content and quality of feeds, but also their digestibility (Ayasan et al., 2020). The rumen environment is simulated using the in vitro daisy incubator to determine digestibility, and the results obtained in this way are generally used in the feeding of ruminants (K1liç and Abdiwali, 2016).

In vitro TNFD is a method used to evaluate the rate and extent of fiber digestion in grasses. It is also used to make comparisons between species (Combs, 2015). In this method, measurements are made at the $24^{\text {th }}, 30^{\text {th }}$, and $48^{\text {th }}$ hours to determine the rate of NDF digestion. Then the calculations are made to predict in vivo digestion in dairy cows by matching the digestion rate and fiber transit rate of NDF (Combs, 2015; Lopes et al., 2015). In their study, Ozelcam et al. (2015) reported the contents of neutral detergent fiber and acid detergent fiber in caramba dry grass as $59.08 \%$ and $38.26 \%$, respectively. In the same study, the digestion coefficients of caramba were reported to be $79.58 \%$ and $81.37 \%$ in the groups of dry matter and organic matter, respectively. Çelik and Selçuk (2019) reported that the addition of vetch and alfalfa hay to caramba caused an increase in vitro true dry matter, in vitro true organic matter digestibility, and in vitro neutral detergent fiber digestibility.

\begin{tabular}{|c|c|}
\hline \multicolumn{2}{|c|}{ RFQ Age and physiological period of dairy cattle } \\
\hline $140-160$ & Until the peak of lactation \\
\hline $125-150$ & $\begin{array}{l}\text { Last } 200 \text { days of lactation and 3-12-month-old heifers } \\
\text { and calves }\end{array}$ \\
\hline $115-130$ & 12-18-month-old heifers \\
\hline $100-120$ & 18-24-month-old heifers \\
\hline$<100$ & Cattle of other ages and classifications \\
\hline
\end{tabular}

The main purpose of this study was to determine the RFQ, total nutrient digestibility, in vitro true digestibility, and the contents of acid detergent fiber, neutral detergent fiber, crude protein, metabolizable energy, net energy lactation in some grass forage plants growing naturally in the pastures of Erzurum province.

\section{MATERIAL AND METHOD}

The research material consisted of 3 grass forage plants [Orchardgrass (Dactylis glomerata), Variegated brome (Bromus variegatus), and intermediate wheatgrass (Agropyron intermedium)] collected from the pastures of Erzurum province in June and July 2019 in Turkey. The plants were harvested at the heading stage, and the samples for each plant were collected from 10 different locations and blended to represent the plant composition in the harvest area (Canbolat and Karaman, 2009). In 2019, the highest temperature in Erzurum was in August with an average of $20.2^{\circ} \mathrm{C}$ and the minimum precipitation was in July with an average of $3 \mathrm{~mm}$.

\section{Determining the nutrient contents of the feeds}

The analyzes of dry matter (DM), crude protein (CP), and crude ash (CA) were carried out as specified by AOAC (1988), and the crude fat (CF) analysis was carried out in line with AOCS Am 5-04 using AnkomXT15 extraction system. The acid detergent fiber (ADF), neutral detergent fiber (NDF), and crude cellulose (CC) analyses were carried out using an ANKOM2000 Fiber Analyzer (Ankom Technology, Macedon NY), and the acid detergent lignin (ADL) was determined using the method reported by Van Soest et al. (1991). The cellulose content was determined by calculation (Cel = ADF-ADL) (Hindrichsen et al., 2006).

Determining the organic matter digestibility (OMD), metabolizable energy (ME), and net energy lactation $\left(\mathrm{NE}_{\mathrm{L}}\right)$ levels of the feed samples.

The in vitro gas test was modified and applied to measure the gas production of the feed samples under in vitro conditions (Menke et al., 1979; Menke and Steingass 1988; Blümmel and Ørskov 1993).

Metabolizable energy (ME) and net energy lactation (NEL) of the feed raw materials were calculated using the equation reported by Menke and Steingass (1988).

$\mathrm{ME}, \mathrm{MJ} / \mathrm{kg} \mathrm{DM}=2.20+0.1357 \mathrm{xGP}+0.057 \mathrm{xCP}+$ $0.002859 \times \mathrm{CF} 2$

$\mathrm{NE}_{\mathrm{L}}(\mathrm{MJ} / \mathrm{kg} \mathrm{DM})=0.101 \times \mathrm{GP}+0.051 \times \mathrm{CP}+0.112 \times \mathrm{CF}$

(GP: Net gas production from $200 \mathrm{mg}$ dry feed sample at the end of a 24-hour-incubation, CP: Crude protein \%, CF: Crude fat $\%$; CA: Crude ash \%).

Emir. J. Food Agric • Vol $33 \bullet$ Issue 5 • 2021 
$\mathrm{TDN}=(\mathrm{NFC} * .98)+(\mathrm{CP} * .93)+(\mathrm{FA} * .97 * 2.25)+(\mathrm{NDFn}$ $*(\mathrm{NDFD} / 100))-7$ (NRC, 2001)

Where:

$\mathrm{CP}=$ crude protein $(\%$ of $\mathrm{DM})$

$\mathrm{EE}=$ ether extract $(\%$ of $\mathrm{DM})$

$\mathrm{FA}=$ fatty acids $(\%$ of $\mathrm{DM})=$ ether extract -1

$\mathrm{NDF}=$ neutral detergent fiber $(\%$ of $\mathrm{DM})$

NDFCP $=$ neutral detergent fiber crude protein

$\mathrm{NDFn}=$ nitrogen free NDF $=\mathrm{NDF}-\mathrm{NDFCP}$, else

estimated as NDFn $=\mathrm{NDF}^{*} .93$

$\mathrm{NDFD}=48$-hour in vitro NDF digestibility ( $\%$ of $\mathrm{NDF}$ )

$\mathrm{NFC}=$ non fibrous carbohydrate $(\%$ of $\mathrm{DM})=100-$ $(\mathrm{NDFn}+\mathrm{CP}+\mathrm{EE}+$ ash $)$.

\section{In vitro digestibility and relative feed quality of the feeds}

In vitro digestibility parameters were determined using an Ankom Daisy incubator, and the buffer solutions were prepared in line with the recommendations for the Ankom Daisy in vitro fermentation system. The rumen content was taken from 2 mature female cattle ( 7 years old) which were brought to be slaughtered at the Meat and Fish Institution operating in Erzurum Province. The rumens of the animals were opened about 5 minutes after the slaughter. The contents of different rumen pouches were put into a thermos that already contained $\mathrm{CO}_{2}$ at $39^{\circ} \mathrm{C}$, and it was immediately brought to the Feed Laboratory, Department of Zootechnics, Faculty of Agriculture, Atatürk University. The rumen liquid was filtered using a four-layer gauze in an environment with $\mathrm{CO}_{2}$ at $39^{\circ} \mathrm{C}$. The $\mathrm{pH}$ of the rumen fluid was 6.35 .

The temperature of the buffer solutions was adjusted to $39^{\circ} \mathrm{C}$. The buffer solutions with the amounts specified in the procedure were mixed in a 2-liter flask. $1600 \mathrm{ml}$ of the buffer solution mixture was poured into each digestion unit of the incubator. The digestion units were placed in the incubator, $400 \mathrm{ml}$ of rumen fluid was added to the buffer solution in each digestion unit at $39^{\circ} \mathrm{C}$, and the prepared bags were placed in the digestion units. $\mathrm{CO}_{2}$ gas was added to maintain the anaerobic environment, and the mixture was incubated for 48 hours. After the incubation, the incubation medium in the digestion units was removed by pouring. The bags were washed under running tap water until they were cleaned completely. Then, they were taken to the Ankom fiber analyzer, and NDF procedure was applied. The true dry matter digestibility (TDMD), true organic matter (TOMD), and true NDF digestibility (TNDFD) of the samples were calculated based on the difference between the amount incubated initially and the amount after the NDF procedure (Çelik and Selçuk, 2019).
The RFQ was calculated using the following equation: RFQ (Relative feed quality $)=(\mathrm{DMI}, \mathrm{DM} \%) *(\mathrm{TDN}$, DM\%)/1.23 (Ward and Ondarza, 2008).

\section{Statistical analysis}

The level of statistical significance for each feed was determined using one-way analysis of variance. Duncan test was used to determine the statistical differences. The statistical analyses were carried out using SPSS 24 (IBM, 2016) software package.

\section{RESULTS AND DISCUSSION}

\section{Chemical composition of the feeds}

The nutrient contents of the grass forage plants are given in Table 2. As can be seen in the Table 2, there were significant differences between the green grass crops in terms of chemical composition $(\mathrm{P}<0.01)$, except for the crude ash content $(\mathrm{P}>0.05)$.

The DM, CA, CF, CP, CC, ADF, NDF, and ADL contents of the variegated brome, intermediate wheatgrass, and orchardgrass were found to be within the range of 7.84$9.14 \%, 93.23-94.10 \%, 1.46-3.06 \%, 13.47-19.56 \%$, 20.88$27.49 \%, 26.49-34.14 \%, 56.46-66.23 \%$, and $\% 5.45-8.52$, respectively. The highest $\mathrm{CP}$ was found to be in the green intermediate wheatgrass with $19.56 \%$ and the lowest in the green orchardgrass with $13.47 \%$. The CP contents of the green grass crops were within the limits reported by Sayar et al. (2014), Başbağ et al. (2018), and Çelik and Selçuk (2019), but higher than those reported by Boureanu et al. (2016), Brown et al. (2018), Fekadu et al. (2018), Holman et al. (2018), and Artan and Polat (2019) who studied the varieties of grass crops.

Orchardgrass was found to have the highest NDF, ADF, and ADL contents with $66.23 \%, 34.14 \%$, and $8.52 \%$, respectively. While the NDF and ADF contents of the green grass crops were in line with those reported in several studies (Berti and Zwinger, 2011; Yavuz and Karadağ, 2016; Holman et al., 2018; Çelik and Selçuk, 2019); they were lower than those reported by Artan and Polat (2019) for the green rhodes grass, bermuda grass, and dallis grass. Again, the NDF and ADF values found in the present study were lower than those reported by some researchers for green grass crops (Cinar and Hatipoglu, 2015; Fekadu et al., 2018). High NDF values slow down the digestion and, by doing so, cause the animal to feel full physically, which decreases the amount of feed intake (Harper and McNeill, 2015). So, low amounts of ADF and ADL are preferred in choosing feed. Berti and Zwinger (2011) reported that the ADL contents were within the range of $3.8-5.9 \%$ for the cool-season annual forages. Considering the chemical 
Table 2: Chemical composition of the grass forage plants (DM \%)

\begin{tabular}{lccccccccc}
\hline Feeds & DM & CA & CF & CP & CC & NDF & ADF & ADL \\
\hline Variegated brome & $8.63^{\mathrm{b}}$ & 93.23 & $1.81^{\mathrm{b}}$ & $15.75^{\mathrm{b}}$ & $21.62^{\mathrm{b}}$ & $56.46^{\mathrm{b}}$ & $27.29^{\mathrm{b}}$ & $7.74^{\mathrm{a}}$ \\
Intermediate & $9.14^{\mathrm{a}}$ & 94.10 & $3.06^{\mathrm{a}}$ & $19.56^{\mathrm{a}}$ & $20.88^{\mathrm{b}}$ & $57.82^{\mathrm{b}}$ & $26.49^{\mathrm{c}}$ & $5.45^{\mathrm{b}}$ \\
wheatgrass & & & & & & & & \\
Orchardgrass & $7.84^{\mathrm{c}}$ & 93.84 & $1.46^{\mathrm{c}}$ & $13.47^{\mathrm{b}}$ & $27.49^{\mathrm{a}}$ & $66.23^{\mathrm{a}}$ & $34.14^{\mathrm{a}}$ & $8.52^{\mathrm{a}}$ \\
SEM & 0.22 & 0.46 & 0.24 & 0.95 & 1.05 & 1.53 & 1.21 & 0.47 \\
Statistical significance & $* *$ & NS & $* *$ & $* *$ & $* *$ & $* *$ & $* *$ & $* *$ \\
\hline
\end{tabular}

SEM: Standard error of mean, ${ }^{* *}$ : P<0.01, NS: Not significant, DM: Dry matter, CA: Crude ash, CF: Crude fat, CP: Crude protein, CC: Crude cellulose, NDF: Neutral detergent fiber, ADF: Acid detergent fiber, ADL: Acid detergent lignin

values found in the present study, it can be asserted that the green intermediate wheatgrass had a higher feeding value than the other green grass crops.

\section{ME, NEL, and TDN contents of the feeds}

Table 3 shows the ME, NEL and TDN of the green grass crops used in the study.

The ME and NEL contents of the green grass crops were within the ranges of $6.85-8.82 \mathrm{MJ} \mathrm{kg} \mathrm{DM}$ and 3.73$5.42 \mathrm{MJ} / \mathrm{kg} \mathrm{DM}$, respectively. The highest ME and NEL contents were found to be in the intermediate wheatgrass and the lowest in the orchardgrass, and the differences between the feeds were significant $(\mathrm{P}<0.01)$. The reason why the ME and NEL contents were low in the green orchardgrass may be explained by the fact that its CP and CF contents were lower than the others. Moreover, orchardgrass was also negatively affected by the increase in the cell wall components (NDF, ADF and ADL), which decreased its digestibility. The ME and NEL levels found in the present study were in line with those reported (6.47 and 3.6-4 MJ $/ \mathrm{kg}$, respectively) by Kılliç et al. 2015, but lower than those reported by Canbolat (2012) (9.1-10.9 and 5.4-6.9 MJ/kg, respectively) and Ayaşan et al. (2017) (11.45-12.79 and 6.94-7.95 MJ/kg, respectively).

The TDN values of the green grass crops varied between $68.79 \%$ and $71.40 \%$. The differences between the values were not significant $(\mathrm{P}>0.05)$. The TDN values found in the present study were higher than those reported by several researchers (Berti and Zwinger, 2011; Sayar et al. 2014; Holman et al. 2018) (62.8\%, 57.5\%, and 57.91\%, respectively). Total digestible nutrient is often used as an indicator of grass quality. The higher the TDN, the higher the grass quality. TDN represents the sum of all digestible organic nutrients in the feed. It also gives information about the energy value in feeding (Troll and Davison, 2000). The differences between the green grass crops forage plants in terms of TDN were not significant.

\section{In vitro digestibility and RFQ values of the feeds}

Table 4 shows the in vitro digestibility parameters and RFQs of the grass forage plants. As can be seen in the Table 4, the differences between the grass forage plants were not
Table 3: Metabolizable energy, net energy, and total digestible nutrient contents (DM) of the grass forage plants

\begin{tabular}{lccc}
\hline Feeds & ME (MJ/kg) & NE (MJ/kg) & TDN (\%) \\
\hline Variegated brome & $7.85^{\mathrm{b}}$ & $4.54^{\mathrm{b}}$ & 73.43 \\
Intermediate & $8.82^{\mathrm{a}}$ & $5.42^{\mathrm{a}}$ & 71.40 \\
wheatgrass & & & \\
Orchardgrass & $6.85^{\mathrm{c}}$ & $3.73^{\mathrm{c}}$ & 68.79 \\
SEM & 0.29 & 0.24 & 0.86 \\
Statistical significance & $* *$ & $* *$ & $\mathrm{NS}$ \\
\hline
\end{tabular}

SEM: Standard error of mean, ${ }^{* *}: \mathrm{P}<0.01$, NS: Not significant, ME: Metabolizable energy, NEL: Net energy lactation, TDN: Total digestible nutrient.

Table 4: In vitro digestibility parameters and relative feed qualities of the grass forage plants (DM)

\begin{tabular}{lcccc}
\hline Feeds & $\begin{array}{c}\text { TDMD } \\
(\%)\end{array}$ & $\begin{array}{c}\text { TNDFD } \\
(\%)\end{array}$ & $\begin{array}{c}\text { TOMD } \\
(\%)\end{array}$ & RFQ \\
\hline Variegated brome & 70.03 & 58.82 & $97.45^{\mathrm{ab}}$ & $149.79^{\mathrm{a}}$ \\
Intermediate & 65.92 & 56.02 & $97.75^{\mathrm{a}}$ & $138.29^{\mathrm{ab}}$ \\
wheatgrass & & & & \\
Orchardgrass & 67.85 & 58.40 & $97.04^{\mathrm{b}}$ & $122.24^{\mathrm{b}}$ \\
SEM & 1.97 & 1.07 & 0.12 & 4.74 \\
Statistical significance & $\mathrm{NS}$ & $\mathrm{NS}$ & ${ }^{*}$ & $*$ \\
\hline
\end{tabular}

SEM: Standard error of mean, *: P<0.05, NS: Not significant, TDMD: True dry matter digestibility, TNDFD: True NDF digestibility, TOMD: True organic matter digestibility, RFQ: Relative feed quality.

significant in terms of TDMD and TNDFD ( $>>0.05)$, but significant in terms of TOMD and RFQ $(\mathrm{P}<0.05)$. The highest TOMD was found to be in the intermediate wheatgrass $(97.75 \%)$, and the lowest in the orchardgrass (97.04\%). The reason why the orchardgrass had the lowest in vitro digestibility parameters may be due to the high values of cell wall contents it had.

There are big differences between plant species in terms of feed quality (Linn and Martin, 1999). Grass crops contain more digestible cellulose than legumes (Rebole et al., 2004). In their study comparing the techniques of estimating the digestibility of feeds, Damiran et al. (2008) reported that the DM and NDF digestion values found in Daisy" method were higher than those found in vitro and in situ methods. Genç et al. (2020) examined the effect of the addition of fumaric and malic acids to some alternative feeds on their in vitro true digestibility for ruminants and reported that the TDMD values were within the range of $45.47-60.66 \%$, the TNDFD values were within the range 
of $11.17-17.46 \%$, and the TOMD values were within the range of $45.40-60.63 \%$.

Relative feed quality is an index comparing the total digestible nutrients by combining fiber digestibility and CP in similar feeds. It is a measure of digestibility (Holman et al., 2018). The RFQs were found to range between 122.24 and 149.79 in the present study. The differences between the plants were found to be significant in terms of RFQ. According to the quality classification reported by Marsalis et al. (2009), the variegated brome was found to be classified as "the best" with the highest RFQ and the orchardgrass was found to be classified as "good" with the lowest RFQ. The CP contents were in harmony with the RFQs. The RFQ values found in the present study were lower than those reported by Kazemi et al. (2012) and Holman et al. (2018), higher than those reported by Boureanu et al. (2016), and similar to those reported by Berti and Zwinger (2011) and Fekadu et al. (2018).

\section{CONCLUSION}

This study was carried out to reveal the nutritional values of some green grass forage plants. The CP and CF contents of the feeds affected their ME and NEL. The CP values affected the RFQs, and the variegated brome was found to have the highest RFQ. When all the results are evaluated together, it can be asserted that the green grass forage plants examined in this study have an important potential in ruminant feeding. Moreover, based on the evaluation of the RFQs according to the physiological periods in dairy cattle, 12-18-month-old heifers can be fed with orchardgrass, 3-12-month-old heifers and calves and the dairy cattle at the last 200 days of lactation with intermediate wheatgrass, and 12-18-month-old heifers and the dairy cattle at the peak or the last 200 days of lactation with variegated brome.

In conclusion, the green grass forage plants examined in this study can be used to eliminate the quality roughage deficit.

\section{ACKNOWLEDGMENTS}

This study was supported by the Scientific Research Projects commission of Ağri İbrahim Çeçen University (Project No: ECOHÜYO.19.001).

\section{Statement of Conflict of Interest}

Authors have declared no conflict of interest.

\section{Authors' Contributions}

EG conceived the study design, data acquisition, and performed the experiments together with AK. AK carried out the data analysis. MG proofread the manuscript.

\section{REFERENCES}

Adesogan, A., L. Sollenberger and J. Moore. 2006. Forage quality. In: C. G. Chambliss (Ed.), Cooperative Extension Services. University of Florida, Florida.

Alçiçek, A. 2001. New Techniques in Feeding Dairy Cows. Ege Agricultural Research Institute Publications.

Artan, H. and T. Polat. 2019. Determining forage quality values in sole and mixtures sowings of some warm season perennial grasses species with alfalfa in the ırrigated conditions of Şanlıurfa. Harran Univ. Vet. Facult. J. 8: 85-92.

Ayaşan, T., İ. Ülger, M. Baylan, M. N. Dinçer, H. Barut, S. Aykanat, H. E. Erten, A. A. Ezici, Ş. Yaktubay and C. Mızrak. 2017. Determination of the nutritive value of some durum wheat (Triticum durum I.) varieties developed using in vitro gas production technique. Iğdır Univ. J. Inst. Sci. Tech. 7: 309-315.

Ayaşan, T., E. Sucu, I. Ülger, H. Hizli, P. Cubukcu and B. D. Ozcan. 2020. Determination of in vitro rumen digestibility and potential feed value of tiger nut varieties. S. Afr. J. Anim. Sci. 50: 738-744.

Ayasan, T., I. Ulger, A. N. Cil, V. Tufarelli, V. Laudadio and V. Palangi. 2021. Estimation of chemical composition, in vitro gas production, metabolizable energy, net energy lactation values of different peanut varieties and line by Hohenheim in vitro gas production technique. Semin. Cienc. Agrarias. 42: 907-920.

Başbağ, M., E. Çaçan and M. S. Sayar. 2018. Determining feed quality values of some grass species and assessments on relations among the traits with biplot analysis method. J. Field Crops Central Res. Inst. 27: 92-101.

Barsila, S. R. 2018. The fodder oat (Avena sativa) mixed legume forages farming: Nutritional and ecological benefits. J. Agric. Nat. Resources. 1: 206-222.

Berti, M. and S. Zwinger. 2011. Cool-season Annual Forages for Hay in North Dakota. Forage Focus-Hay, Dakota. p. 1-2.

Blümmel, M. and E. R. Ørskov. 1993. Comparison of in vitro gas production and nylon bag degradabilities of roughages in predicting food intake of cattle. Anim. Feed. Sci. Technol. 40: 109-119.

Brown, A. N., G. Ferreira, C. L. Teets, W. E. Thomason and C. D. Teutsch. 2018. Nutritional composition and in vitro digestibility of grass and legume winter (cover) crops. J. Dairy Sci. 101: 2037-2047.

Boureanu, C. C., M. Stavarache, C. Samull and V. Vîntu. 2016. Influence of fertilization on forage quality of the simple mixtures between Bromus inermis Leyss. and Onobrychis viciifolia Scop. Luc. Ştiin. 59: 189-192.

Canbolat, Ö. and Ş. Karaman. 2009. Comparison of in vitro gas production, organic matter digestibility, relative feed value and metabolizable energy contents of some legume forages. J. Agric. Sci. 15: 188-195.

Canbolat, Ö. 2012. Comparison of in vitro gas production, organic matter digestibility, relative feed value and metabolizable energy contents of some cereal forages. Kafkas Univ. Vet. Fac. J. 18: 571-577.

Combs, D., 2015. Forage Quality and Utilization: Total Tract NDF Digestibility. Proceedign of the Western States Alfalfa and Forage Symposium.

Çelik, H. and Z. Selçuk. 2019. Determination of in vitro true digestibilities of different rates of vetch hay and alfalfa hay with caramba. Van Vet. J. 30: 145-149.

Cınar, S. and R. Hatipoglu. 2015. Quality characteristics of the mixtures of some warm season perennial grasses with alfalfa (Medicago sativa I.) under irrigated conditions of Cukurova. Turk. J. Field Crops. 20: 31-37.

Damiran, D., T., DelCurto, D. W. Bohnert and S. L. Findholt. 2008. 
Comparison of techniques and grinding size to estimate digestibility of forage based ruminant diets. Anim. Feed Sci. Technol. 141: 15-35.

Favrea, J. R., T. M. Castiblancob, D. K. Combsb, M. A. Wattiauxb and V. D. Picassoa. 2019. Forage nutritive value and predicted fiber digestibility of Kernza intermediate wheatgrass in monoculture and in mixture with red clover during the first production year. Anim. Feed Technol. 258: 114298.

Fekadu, D., M. Walelegn and G. Terefe. 2018. Nutritional comparison of feed resources for ruminant animals feeding in Ethiopia using relative forage quality. J. Nat. Sci. 8: 1-8.

France, J., M. Theodorou, R. Lowman and D. Beever. 2000. Feed evaluation for animal production. In: Feeding Systems and Feed Evaluation Models. CABI Publishing, Wallingford, Oxfordshire, pp. $12-20$

Genç, B., M. Salman, B. Bölükbaş, İ. Kaya and M. Açıcı. 2020. The effects of fumaric and malic acids on the in vitro true digestibility of some alternative feedstuffs for ruminants. Vet. J. Ankara Univ. 67: 185-192.

Gülcan, H., Anlarsal, A. E., Yücel, C. 2002. Principles of Feed Culture. C.U. Faculty of Agriculture General Publication No: 117, Textbooks Publication No: A-32, Adana, p. 72.

Harper, K. J. and D. M. McNeill. 2015. The Role iNDF in the regulation of feed intake and the importance of its assessment in subtropical ruminant systems (the Role of iNDF in the regulation of forage intake). Agriculture. 5: 778-790.

Hindrichsen, I. K., M. Kreuzer, J. Madsen and K. E. B. Knudsen. 2006. Fiber and lignin analysis in concentrate, forage, and feces: Detergent versus enzymatic-chemical method. J. Dairy Sci. 89: 2168-2176.

Holman, J. D., A. Obour, T. Roberts and S. Maxwell. 2018. Forage type and maturity effects on yield and nutritive value. Kansas Agric. Exp. Station Res. Rep. 4: 7636.

IBM. 2016. IBM SPSS Statistics for Windows, Version 24.0. Computer Hardware Company, Armonk.

Kılıç, Ü., S. Yurtseven, M. Boğa and S. Aydemir. 2015. Effects of soil salinity levels on nutrient contents and in vitro gas productions of some grass crops forages. Soil Sci. Soc. Turk. 3: 9-15.

Kılıç, Ü. and M. A. Abdiwali. 2016. Determination of in vitro true digestibilities and relative feed values of wine industry grape residues as alternative feed source. Kafkas Univ. Vet. Fac. J. 22: 895-901.

Lopes, F., K. Ruh and D. K. Combs. 2015. Validation of an approach to predict total-tract fiber digestibility using a standardized in vitro technique for different diets fed to high-producing dairy cows. J. Dairy Sci. 98: 2596-2602.

Linn, J. G. and N. P. Martin. 1999. Forage Quality Tests and Interpretations. Fact Sheet AGFO-2637. Minnesota Extension Service, University of Minnesota, St. Paul.

Marsalis, M. A., G. R. Hagevoort and L. M. Lauriault. 2009. Hay quality, sampling, and testing. New Mexico State University, USA, Circular, pp. 1-8.

Menke, K. H., L. Raab, A. Salewski, H. Steingass, D. Fritz and W. Schneider. 1979. The estimation of the digestibility and metabolisable energy content of ruminant feding stuffs from the gas production when they are incubated with rumen liquor. J. Agric. Sci. 93: 217-222.

Menke, K. H. and H. Steingass. 1988. Estimation of the energetic feed value obtained from chemical analysis and in vitro gas production using rumen fluid. Anim. Res. Dev. 28: 7-55.

Muir, J., B. Lambert and Y. Newman. 2007. Defining forage quality. J. Nat. Sci. Res. 8: 1-5.
Newman, Y. C., B. Lambert and J. P. Muir. 2006. Defining Forage Quality. The Texas A\&M University System, U.S. Department of Agriculture, and the County Commissioners Courts of Texas Cooperating, pp. 1-13.

NRC. 2001. Nutrient Requirements of Dairy Cattle. $7^{\text {th }}$ ed. National Research Council, Washington, DC, p. 381.

Oyedele, O. J., V. O. Asaolu and S. M. Odeyinka. 2016. Nutrient digestibility and growth performance of West African dwarf (wad) goats fed foliage combinations of Moringa oleifera and Gliricidia sepium with equal proportions of a low-cost concentrate. J. Nat. Sci. Res. 6: 20-29.

Özelçam, H., F. Kırkpınar and K. Tan. 2015. Chemical composition, in vivo digestibility and metabolizable energy values of Caramba (Lolium multiflorum cv. Caramba) fresh, silage and hay. Asian Australas J. Anim. Sci. 28: 1427-1432.

Pinkerton, B., D. L. Cross and C. U. C. E. Service. 1991. Forage Quality: Cooperative Extension Service. Clemson University, Clemson, South Carolina.

Rebole, A., C. Alzueta, L. T. Ortiz and C. Baro. 2004. Yield and chamical composition of different parts of the common vetch at flowering and two seed filling stages. Span J. Agric. Res. 2: 550-557.

Salama, H. S. A. and M. M. K. Zeid. 2016. Hay quality evaluation of summer grass and legume forage monocultures and mixtures grown under irrigated conditions. Aust. J. Crop Sci. 10: 1543-1550.

Sayar, M. S. and E. Kendal. 2014. Mixed sowing of annual legume forage crops with cereals. Mardin J. Food Agric. Livest. 4: 52-54.

Sayar, M. S., Y. Han, H. Yolcu and H. Yücel. 2014. Yield and quality traits of some perennial forages as both sole crops and intercropping mixtures under irrigated conditions. Turk. J. Field Crops. 19: 59-65.

Schut, A., S. Gherardi and D. Wood. 2010. Empirical models to quantify the nutritive characteristics of annual pastures in SouthWest Western Australia. Crop Pasture Sci. 61: 32-43.

Serin, Y. and M. Tan. 2009. In: R. Avcıoğlu, R. Hatipoğlu and Y. Karadağ (Ed.), Agricultural Characteristics of Wheatgrass Forage Crops, Economic Importance, Taxonomies and General Structural Features, Forage Crops from Wheat and Other Families. Vol. 3. TÜGEM, Emre Publishing House, İzmirm, pp. 546-549.

Sevov, A., C. Yancheva and Y. Kazakova. 2018. Sustainable pasture management. In: New Perspectives in Forage Crops. BoD Books on Demand, Norderstedt, Germany.

Troll, R. and J. Davision. 2000. Improwing grass hay quality through fertilizer and irrigation management. Intermountain Pasture and Hay Meadow Handbook, University of Nevada, Reno, Cooperative Extension.

Undersander, D. 2003. The New Relative Forage Quality Index Concept and Use. World's Forage Superbowl Contest, UWEX.

Van Soest P. J., J. B. Robertson and B. A. Lewis. 1991. Methods for dietary fiber, neutral detergent fiber, and nonstarch polysaccharides in relation to animal nutrition. J. Dairy Sci., 74: 3583-3597.

Ward, R. and M. B. Ondarza. 2008. Relative feed value (RFV) vs. Relative Forage Quality (RFQ), Cumberland Valley Analytical Services, INC Hagestown, MD, Paradox Nutrition, LLC, West Chazy, NY.

Yancheva, C., S. Angelova and R. Koeva. 2002. Management of steppe habitats in pastures of the region of Kaliakra reserve in Bulgaria. In: $19^{\text {th }}$ General Meeting of EGF in Multifunction Grasslands, La Roshelle, France, pp. 860-862. 